\title{
FAIR TRADE AND THE ART OF PRESTIDIGITATION
}

\section{WALTER ADAMS†}

A RECENT article by Professor Herman in answer to an article of mine on the subject of fair trade ${ }^{1}$ prompts this reply. Since the record speaks for itself, I do not propose to comment on Professor Herman's techniques of disputation.

\section{Fair Trade and the Consuner}

Professor Herman objects to my statement that the case against fair trade rests on highly questionable evidence. ${ }^{2}$ He does not consider it meaningful and accurate to say that, so long as there is effective competition among manufacturers, fair trade is not likely to prove injurious to the consumer, but contends on the contrary that since fair traded products "are frequently sold in markets of few sellers ... significant factors are already at work tending to reduce the effectiveness of competition."3

Competitive conditions and structural characteristics vary, of course, from industry to industry, and only a case-by-case investigation can yield statistically significant results. However, we do have fragmentary evidence which sheds considerable light on the extent of competition among fair traded products and between fair traded and non-fair traded products.

First, it is noteworthy that there are 11,842 manufacturers of nationally advertised, brand-name products in 43 industrial classifications listed by the Standard Advertising Register, and, as Table I indicates, the percentage of fair trading manufacturers in each of these broad classifications is by no means staggering. 4

Although Table I probably understates the extent of fair trading (because it includes only broad industry categories), there is little evidence to support the contention that " it is nearly always impossible for one manufacturer to establish a system of vertical price fixing unless he can be sure that his competitors will do likewise. ..." "s The recent abandonment of fair trade by some electric

$\dagger$ Associate Professor of Economics, Michigan State University.

1. Herman, $A$ Note on Fair Trade, 65 Y ALE L.J. 23 (1955), criticizing Adams, Resale Price Maintenance: Fact and Fancy, $64 \mathrm{id}$. at 967.

2. Herman, sitpra note 1, at 23.

3. Id. at 25 .

4. Hearings Before the Antitrust Subcommittee of the House Committee on the Judiciary on Resale Price Maintenance, 82d Cong., 2d Sess., ser. 12, at 757 (1952) (hereinafter cited as Hearings).

5. This is the statement of Corwin Edwards, quoted with approval in Herman, supra note 1 , at 27 . The facts of the market place simply do not substantiate the charge that "horizontal collusion in violation of the law has been an indispensable part of the movement for resale price maintenance." Ibid. In some lines there are more fair traded goods 


\section{Industrial Classification}

Heating

Radio and television

Furniture, floor covering, decorations, and upholstery

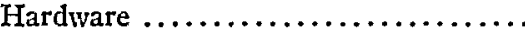

Household appliances...$\ldots \ldots \ldots \ldots$.

House furnishings ................

Cleansers .......................

Smokers' requisites ................

Flour and cereals ................

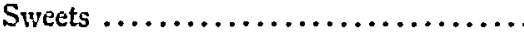

Coffee and tea $\ldots \ldots \ldots \ldots \ldots \ldots \ldots \ldots$

Food products ....................

Wines and liquors..$\ldots \ldots \ldots \ldots \ldots$

Beer, ale, and soft drinks ...........

Women's clothing and furnishings .....

Fancy goods and notions, etc. .........

Knit goods and underwear ..........

Men's clothing and furnishings ........

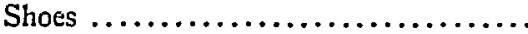

Jewelry, silverware, etc. ............

Toilet requisites..$\ldots \ldots \ldots \ldots \ldots \ldots$.

Proprietary medicines, drugs, chemicals, etc.

Musical instruments, amusements, etc. ..

Sporting goods .................

Watercraft, bicycles, and motorcycles ...

Games, toys, etc.

Publishers, engravers, etc. ............

Airplanes and accessories ............

Automobiles and trucks .............

Trailers, pleasure .................

Tires and tubes ..................

Gasoline and lubricants .............

Automobile accessories ..............

Building construction and material .....

Paints, varnishes, and enamels .........

Machinery and supplies .............

Office Equipment .................

Mail Order Houses .................

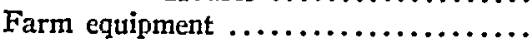

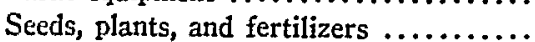

Livestock, poultry, and supplies

Miscellaneous

Total, 43 classifications
TABLE I

\begin{tabular}{|c|c|c|}
\hline $\begin{array}{l}\text { NunfBER OF } \\
\text { MANUFAC- }\end{array}$ & & \\
\hline TURERS LISTED & NUMBER OF & PER CENT OF \\
\hline BY STANDARD & FAIR Trading & FAIR Trading \\
\hline ADVERTISING & ManUfac- & Manufac- \\
\hline REGISTER & TURERS & TURERS \\
\hline 244 & 11 & 4.51 \\
\hline 150 & 7 & 4.67 \\
\hline 158 & 8 & 5.06 \\
\hline 330 & 16 & 4.85 \\
\hline 337 & 33 & 9.79 \\
\hline 142 & 18 & 12.68 \\
\hline 553 & 82 & 14.83 \\
\hline 213 & 53 & 24.88 \\
\hline 110 & 46 & 41.82 \\
\hline 76 & 6 & 7.89 \\
\hline 137 & 3 & 2.19 \\
\hline 59 & 4 & 6.78 \\
\hline 861 & 44 & 5.11 \\
\hline 165 & 13 & 7.88 \\
\hline 251 & 7 & 2.79 \\
\hline 741 & 5 & 0.67 \\
\hline 335 & 16 & 4.78 \\
\hline 230 & 13 & 0.57 \\
\hline 295 & 9 & 3.05 \\
\hline 250 & 5 & 2.0 \\
\hline 248 & 37 & 14.92 \\
\hline 402 & 61 & 15.17 \\
\hline 620 & 174 & 28.06 \\
\hline 104 & 6 & 5.77 \\
\hline 345 & 65 & 18.84 \\
\hline 86 & 2 & 2.33 \\
\hline 88 & 5 & 5.68 \\
\hline 493 & 48 & 9.72 \\
\hline 72 & 4 & 5.56 \\
\hline 59 & 2 & 3.39 \\
\hline 29 & 0 & - \\
\hline 25 & 5 & 20.0 \\
\hline 109 & 13 & 11.93 \\
\hline 354 & 78 & 22.03 \\
\hline 601 & 12 & 2.0 \\
\hline 175 & 17 & 9.71 \\
\hline 684 & 19 & 2.78 \\
\hline 225 & 51 & 22.67 \\
\hline 36 & 0 & - \\
\hline 338 & 3 & .89 \\
\hline 287 & 9 & 3.14 \\
\hline 204 & 10 & 4.9 \\
\hline 621 & 11 & 1.77 \\
\hline 11,842 & 1,031 & 8.71 \\
\hline
\end{tabular}


appliance producers and its retention by others is but another refutation of this generalization. ${ }^{6}$

Second, many of the individual products that are generally fair traded are subject to intense and effective competition among rival manufacturers. In its "1955 Buying Guide," for example, Consumer Reports (a sharp critic of the fair trade laws) lists 48 brands of tooth paste (not including tooth powder) tested in laboratories. These brands, produced by 32 manufacturers, ranged in price from 7.8 cents to 25 cents per ounce. ${ }^{7}$ The same publication lists 52 brands of cleansing creams, produced by 38 manufacturers, ranging in price from 5 cents to 82 cents per ounce. ${ }^{8}$ Other data compiled by Consumer Reports indicate that there are 56 brands of face powder, ranging from 9 cents to $\$ 1.20$ per ounce; 56 brands of floor wax, ranging from 8 cents to 35 cents per ounce; 76 brands of toilet soap, ranging from 32 cents to $\$ 10.50$ per pound of dry weight; 9 brands of portable typewriters, ranging from $\$ 76.85$ to $\$ 119.67 .9$ With regard to electrical appliances, the Sunbeam Corporation furnished the following data in a complaint against R. H. Macy and Company:

"Electric irons: 17 national brands and 22 private brands: price range from $\$ 3.45$ to $\$ 21.90$.

"Electric toasters: 9 national brands and 12 private brands; price range from $\$ 2.98$ to $\$ 26.50$.

"Electric mixers: 9 national brands and 6 private brands; price range from $\$ 18.75$ to $\$ 76.41$.

"Electric shavers: 10 national brands and 1 private brand; price range from $\$ 15.50$ to $\$ 39.75$."'10

Obviously, the degrees of concentration are different in each of the foregoing manufacturing fields. While economists might regard the concentration among typewriter manufacturers as excessive, it would require considerable temerity to question the effectiveness of competition among manufacturers of face powder, cleansing creams, tooth paste, and hundreds of other products that are generally fair traded. Again I say, therefore, that so long as there is effective competition on the manufacturing level, we need not fear the impact of fair

than in others, but in virtually all lines there are manufacturers who do not fair trade. Moreover, in a sharply increasing number of fields the fair trading manufacturer has to meet the price competition of private (or store-controlled) brands some of which are as national and as widely advertised as the manufacturers' brands. In fact, there is evidence that many (if not all) fair trading manufacturers engage in price competition and refrain from a collusive or systematic "matching" of their competitors' prices. See, e.g., Hearings, supra note 4, at $123-26,737-38,779-80,842$.

6. Westinghouse, for example, abandoned fair trade pricing on electric housewares and bed coverings. Wall Street Journal, Sept. 1, 1955, p. 2, cols. 2-4. Simultaneously, however, it announced an increase in suggested retail prices on toasters from $\$ 19.95$ to $\$ 21.95$ and on the sandwich grill and waffler from $\$ 29.95$ to $\$ 31.95$. The company also announced a projected increase on ten inch fans from $\$ 15.95$ to $\$ 16.95$, on twelve inch fans from $\$ 26.95$ to $\$ 27.95$, and on the Riviera model floor-type fan from $\$ 39.95$ to $\$ 42.95$. Ibid.

7. Consumer Reports, "1955 Buying Guide Issue," Dec. 1954, pp. 201-04.

8. Id. at $187-90$.

9. Hearings, supra note 4 , at 779 .

10. Id. at 780 . 
trade on the consumer pocketbook. For each manufacturer in his search for a larger segment of the market will try to make his price as attractive as possible to the consumer. As Brandeis said, a manufacturer subject to the rigors of competition "establishes his price at his peril-the peril that, if he sets it too high, either the consumer will not buy, or, if the article is nevertheless popular, the high profits will invite even more competition."11

Third, it appears that fair trade opponents have seriously underestimated the competitive impact of private, store-controlled or distributor-controlled brands, some of which are heavily advertised and most of which are readily available to the price-conscious consumer. A survey by the Grey Advertising Agency, for example, yielded the following findings:

"In the shoe field, both men's and women's, the shoe chains are accounting for close to half of the total shoe volume. Most shoe chains feature their own brands exclusively. And they advertise these brands extensively. Indeed the controlled brands of the shoe chains probably get more advertising dollars than the total national advertising budget of the shoe manufacturers who have national brands. . . .

"In women's girdles-a field having a number of strong brands advertised by manufacturers-we find that [in the Spokane, Washington, market] Sears' Charmode is first with 12.6 per cent of consumer preference and Penney is No. 5 with 6.6 per cent. The store-controlled brands of girdles show a total of approximately 21 per cent of consumer preference....

"Macy's reports that over 75 per cent of its television volume is done on its own brands....

"In the candy field, the controlled-and advertised-brands of the chains probably outsell the nationally advertised manufacturers' brands. . . .

"Even in the food field, the store-controlled or wholesaler-controlledand advertised brands-do a gigantic volume. The voluntary chains do just about as large a total volume as the corporate food chains. . . . The IGA label, to cite a solitary example-the label of the Independent Grocers Alliance-apparently accounts for a $\$ 1$ billion volume. ...

"Some 200 large retailers do a bit better than half of the total hosiery volume. Many, if not most, of these large retailers promote their own hosiery brands. These known brands of the large retailers have achieved a volume that certainly runs neck and neck with the total volume done by the manufacturers' advertised brands. . . ."12

While these findings are not here offered as definitive or necessarily typical of all fair traded products, they point up some relevant considerations in appraising the competitive impact of fair trade in the market place.

\section{The "Free and Open Competition" Clause}

Professor Herman repeats the charge that the practical effect of the fair trade laws is to nullify the antitrust prohibitions against horizontal price fixing. $\mathrm{He}$

11. Brandeis, Competition That Kills, Harper's Weekly, Nov. 15, 1913, p. 10, reprinted in Brandeis, Business-A Profession 256-57 (1933).

12. Hearings, supra note 4 , at $759-60$. 
contends that I do not adequately refute this claim, and that I come to grips with it only in oblique fashion by citing the "free and open competition" proviso in the statute. He refuses to regard the latter as a "crucial safeguard against exploitation."13

First, my article cites numerous instances where horizontal conspiracies under the guise of fair trade have been successfully prosecuted as antitrust violations. ${ }^{14}$ Both the Department of Justice and the Federal Trade Commission-perhaps because of their ideological opposition to fair trade-have always scrutinized fair trade pricing with a fine eye, ever elert to prosecute forbidden horizontal arrangements. The enforcement record in this field is an obvious deterrent to a would-be violator of the antitrust laws and clearly minimizes the incentives for horizontal collusion.

Second, while it is true that only a few court decisions so far have interpreted the "free and open competition" proviso, it is also true that the proviso is in the law and that the courts have the power to interpret it in an economically meaningful and realistic fashion. Significantly, the Supreme Court in the Old Dearborn case ${ }^{15}$ rejected the argument that the phrase "fair and open competition" was fatally vague and indefinite. "Certainly," said the Court, "the phrase 'fair and open competition' is as definite as the phrase contained in $\$ 5$ of the Federal Trade Commission Act, 'unfair methods of competition,' which this court had never regarded as being fatally uncertain."16

Professor Herman cites five cases to demonstrate the ineffectiveness of the statutory competition test. ${ }^{17}$ Interestingly enough, four of these cases were private litigations in which the legal and economic resources of such giants of industry as Sparklets Devices, H. Hollander, Sam Goody and H. C. Drescher, ${ }^{18}$ were mobilized to infuse meaning into the "free and open competition" clause. They failed, but the Federal Trade Commission sustained its burden of proof in the only governmental action cited by Professor Herman. ${ }^{19}$ The record to date certainly does not justify dire predictions about the future, especially if the antitrust agencies were to expend as much energy in enforcing the "free and open competition" clause as they now devote to spearheading the drive for repeal of the Miller-Tydings and McGuire Acts. Unless and until the agencies

13. Herman, supra note 1 , at 23-24.

14. Adams, supra note 1, at $971-72$.

15. Old Dearborn Distributing Co. v. Seagram-Distillers Corp., 299 U.S. 183 (1936). The phrase "fair and open competition," typically appearing in state laws, corresponds to the "free and open competition" proviso of the federal law.

16. Id. at 196.

17. Herman, supra note 1, at 26.

18. Ronson Patents Corp. v. Sparklets Devices, Inc., 112 F. Supp. 676 (E.D. Mo. 1953) ; Schenley Distributors, Inc. v. H. Hollander Co., CCH Trade Reg. Rep. If 3154.23 (Mass. Super. Ct. 1940) ; Columbia Records, Inc. v. Goody, 278 App. Div. 401,105 N.Y.S.2d 659 (1st Dep't 1951) ; Carstairs Distillers Corp. v. H. C. Drescher Co., 106 N.Y.L.J. 10, col. 3 (N.Y. Sup. Ct. July 1, 1941).

19. Eastman Kodak Co. v. FTC, 158 F.2d 592 (2d Cir. 1946), cert. denied, 330 U.S. 828 (1947). 
attempt a broad-gauged and comprehensive enforcement program (as repeatedly urged in my article), and unless and until they convincingly demonstrate that the clause is in fact unenforceable, we must continue to look upon "free and open competition" as a possibly useful weapon against consumer exploitation.

Third, a more specific examination of the cases cited by Professor Herman shows that they are not as restrictive as they may seem at first blush. In the Kodak case, the court said that a purchaser of color film "must be able to buy it from more than one manufacturer," 20 but it did not necessarily suggest that only two manufacturers would be enough to meet the statutory competition test. Certainly, the court in defining the market for color film as distinct from black-and-white film was more antitrust-minded than another court which recently defined the market for cellophane. ${ }^{21}$

In the long playing records industry, says Professor Herman, fair trade pricing was upheld despite the fact that 4 firms produced 79 per cent of the 1947 output. Unfortunately, however, Professor Herman fails to point out that LP's did not hit the market until 1947, that plaintiff Columbia Records never fair traded the conventional 78-RPM records, and that it did not begin to fair trade LP's until September 1950. ${ }^{22}$ Hence, the 1947 concentration statistics are of rather limited significance, particularly in view of the court's finding that by 1951 there were 68 companies manufacturing long playing records-companies which used "the same advertising media to reach customers in the same market" and which competed "in the sale of records of the same general class, such as symphonic records, classical soloists, and popular records. Many prominent artists, too, have made recordings for different companies, which recordings are now available to the public."23 By 1953, we might add, there were probably more than 100 manufacturers of LP's and their competition was so intense as to contribute to a drastic reduction of the industry's entire price structure.

The automatic lighter case cited by Professor Herman, Ronson Patents Corp. v. Sparklets Devices, Inc. ${ }^{24}$ was a patent infringement action wherein defendants counterclaimed charging plaintiffs with illegal monopoly and conspiracy in violation of the Sherman Act. The fair trade practices of Ronson were never a central issue in the case, and the court never mentioned the "free and open competition" clause. The court's holding that the defendant had not established the existence of a monopoly, or damage resulting from plaintiff's actions, foreclosed the fair trade issue.

Finally, with respect to the whiskey industry, Professor Herman claims that

20. Id., $158 \mathrm{~F} .2 \mathrm{~d}$ at 594 .

21. United States v. E. I. duPont de Nemours \& Co., 118 F. Supp. 41 (D. Del. 1953). See also Stocking \& Mueller, The Cellophane Case and the Nero Competition, 45 Am. ECoN. Rev. 29 (1955).

22. Columbia Records, Inc. v. Goody, 278 App. Div. 401, 403-04, 105 N.Y.S.2d 659, 662 (1st Dep't 1951).

23. Id. at 405,105 N.Y.S.2d at 663 .

24. 112 F. Supp. 676 (E.D. Mo. 1953). 
the "free and open competition" clause was found to be no bar to fair trading despite the fact that the four largest firms produced 75 per cent of the 1947 output. ${ }^{25}$ In support of this claim he cites two cases, one of which was decided six years and the other seven years before the 1947 concentration ratios were compiled. ${ }^{26}$ Significantly enough, the cases cited by Professor Herman were decided at a time when the four largest producers accounted for only about 50 rather than 75 per cent of the industry's output. ${ }^{27}$ Moreover, in the year that the Carstairs ${ }^{28}$ opinion was announced, the same court denied an injunction to prevent violation of a fair trade agreement because the plaintiff whiskey manufacturer failed to deny defendant's allegations that the products concerned were not in fair and open competition. ${ }^{29}$

Obviously, if the "free and open competition" proviso is to be rejected as an inadequate safeguard against consumer exploitation, more convincing and unidirectional precedents shall have to be adduced. Precedents may be sparse, but the intent of Congress seems clear. For Senator Tydings, in discussing the construction of the "free and open competition" proviso, emphasized that fair trade should be available only where there are enough manufacturers to protect the consumer through a regime of effective competition. Significantly enough he mentioned tooth paste and its many producers to indicate the kind of competition he had in mind. ${ }^{30}$

\section{The "Battle of the Surveys"}

Professor Herman disputes my contention that the "battle of the surveys" has been inconclusive. He avers that "in virtually every instance of a survey carried out by reasonably disinterested parties, the spotty individual studies point to the price increasing or stabilizing effects that we would expect on theoretical grounds."31 The following statements by leading opponents of fair trade (who may qualify as "reasonably disinterested parties") cast doubt on this generalization.

25. Herman, supra note 1, at 25-26.

26. See Schenley Distributors, Inc. v. H. Hollander Co., CCH Trade REg. Rep. If 3154.23 (Mass. Super. Ct. 1940) ; Carstairs Distillers Corp. v. H. C. Drescher Co., 106 N.Y.L.J. 10, col. 3 (N.Y. Sup. Ct. July 1, 1941).

27. FTC, Report on Changes in Concentration in Manufacturing 66-72, 138 (1954). The developments in the whiskey industry between 1940 and 1947 indicate that, from a public policy viewpoint, it is vastly more important to proceed against mergers and acquisitions that substantially lessen competition than to squander inadequate resources on de minimis restraints in vertical pricing arrangements.

28. Carstairs Distillers Corp. v. H. C. Drescher Co., 106 N.Y.L.J. 10, col. 3 (N.Y. Sup. Ct. July 1, 1941).

29. Calvert Distillers Corp. v. Leland Wine \& Liquor Stores, Inc., 105 N.Y.L.J. 2718, col. 1 (N.Y. Sup. Ct. June 17, 1941).

30. See the debate on what became the Miller-Tydings Act, a rider to H.R. 7472. 81 CONG. REC. 7495 (1937).

31. Herman, supra note 1 , at 27-28. (Emphasis added.) 
H. Graham Morrison, former Assistant Attorney General in charge of the Antitrust Division and an outspoken critic of fair trade (who, incidentally, is cited with approval by Professor Herman), ${ }^{32}$ conceded before a congressional committee that:

"Various so-called surveys or studies have been made concerning the effect of resale price maintenance on the consumer's pocketbook. Some of these surveys, run under the aegis of 'fair trade' proponents, purport to show one result, while others, which have been made on a local scale by its opponents, show diametrically opposite results. This is to be expected, by reason of the nature of the problem and the difficulty of being certain that a particular survey has considered all the pertinent problems. So far as I am aware, no study has been made on a wide enough basis to give definite proof of any kind."33

Similarly, Professor E. T. Grether, Dean of the School of Business Administration at the University of California and a persistent critic of fair trade (who is also cited with approval by Professor Herman) ${ }^{34}$ testified:

"In the United States there has not been a sufficiently long period of experience under relatively normal market conditions to appraise the full effects of resale price maintenance implemented by the nonsigner's clause. ... It is important to know that we actually know very little in this country in a measurable sense concerning the full effects of resale price maintenance aver a period of years in normal times. The more important effects of resale price maintenance are in the nature of secondary and longrun repercussions. We have not had adequate evidence of these effects in this country." 35

Finally, Dun and Bradstreet, whose integrity as an information gathering agency has not, to my knowledge, been impugned by anyone, is quoted as saying:

"Our position is that it is virtually impossible, through a survey, to establish the precise effect of fair-trade laws on the consumer's pocketbook. As Mr. Idleman points out, the first phase of the job-that of determining how much of the consumer's dollar is spent for fair-traded items - is in itself a stupendous task. Even if it were feasible to complete that phase, it would mean little unless we could then establish what effect the pricing of fair-traded items has on the prices of non-fair-traded items. We see no way to do that." 36

32. Id. at $26 \mathrm{n} .16$.

33. Hearings, supra note 4 , at 42 . (Emphasis added.)

34. Herman, supra note 1 , at 28 n.24.

35. Hcarings, supra note 4, at 555. (Emphasis added.)

36. Id. at 744-45. The dilemma of the Nielsen study to which Professor Herman refers is no dilemma at all. According to the Bureau of Education on Fair Trade (for whom the Nielsen study was made), the study showed that the fair trade price in the fair trade states tended more often than in the non-fair trade states to become the maximum as well as the minimum price. Thus, according to the Nielsen findings, the over-all weighted average price was higher in the non-fair trade states, despite the quite reasonable assumption that some retail outlets in these states charged substantially less than the fair trade 
Clearly, conservative analysis of the fair trade issue must rest on evidence other than that now available through the survey method.

\section{Loss Leader Selling and Consumer Rationality}

Professor Herman disputes my contention that price cutting in non-fair trade areas merely indicates that loss leader selling exists, and that some consumer bargains may be offset by lemons. "Such an assertion," he says, "rests on an assumption of consumer irrationality which is least appropriate for precisely those persons to whom a unit of money has the most significance." 37

Consumer behavior during the "massacre on 34th Street" (the brief period of price cutting which followed the first Schwegmann decision) ${ }^{38}$ does not inspire much confidence in the consumer's rationality or his ability to separate bargains from lemons. For example, on June 4, 1951, the trade journal Retailing Daily reported that:

"The thousands of customers who came to housewares sections of New York stores to buy Toastmasters and Mixmasters last week stayed to buy a lot more, from can openers to sauce pans, and most of these at regular prices. 'The electrics may have been phenomenal,' one (department store) buyer grinned, 'but you should have seen some of the garbage we were able to get rid of." "39

On June 3, 1951, Edward Davidson, chairman of the board of Bloomingdale's, was quoted as saying:

“It hasn't taken long for retailers to realize that Macy's had no intention of broad, general price-cutting, but merely picked a group of famous names and miscellaneous items for their publicity to give the impression that everything was now cheaper."40

On June 9, 1951, Business Week reported:

"A salient fact about the price cutting in New York is that almost all of it has been on fair-traded items. In other words, price cutting in New York has been largely a promotional deal. When people have been pulled

price for one or more of the twenty-six articles surveyed. The Nielsen findings are corroborated by Herman C. Nolen, vice-president of McKesson \& Robbins and a supporter of fair trade. "We keep a fairly accurate record of our prices," says Mr. Nolen, "and they are not any lower in the non-'Fair Trade' than they are in the 'Fair Trade' states." Conference Board EConomic Forum, The "FaIr Trade" Question 36 (1955). Then, citing the figures of Eli Lilly \& Company, Mr. Nolen claims that drug stores in the fair trade states operate "on slightly lower margins" than their counterparts in the non-fair trade states, although the "difference is not significant." $I d$. at 37. Admittedly, these are claims by avowed supporters of fair trade, but we can hardly refute them by dismissing them. We cannot act like the chess player who wins the game by sweeping his opponent's pieces off the board.

37. Herman, supra note 1 , at 28 .

38. Schwegmann Bros. v. Calvert Distillers Corp., 341 U.S. 384 (1951).

39. Hearings, supra note 4 , at 751.

40. Ibid. 
into the stores on the strength of bargains, they have bought a lot of other things, too....

"In New York the 'price war' promptly pushed department store sales up 25 per cent over the same week a year ago. And it wasn't only fairtraded goods that moved over the counter. Once you get people in the mood to buy, everything doesn't have to go at bargain prices." 41

Consumer "rationality" is often no more than a convenient assumption in economics texts, and anyone who believes that the consumer confines his purchases exclusively to loss leaders must find it rather difficult to explain the popularity of loss leader selling.

\section{Alternatives to Fair Trade}

Professor Herman contends that there are "other methods available for preventing monopolization of the distributive mechanism which do not require the throwing out of the baby (current competition in distribution) with the bath water (loss leaders)."42

Unfortunately, neither Professor Herman nor the Attorney General's Committee ${ }^{43}$ indicates what these methods are nor how effective they are likely to be. Significantly enough, the Miller-Tydings Act was passed in 1937 precisely because the anti-price discrimination statutes had proven woefully inadequate, and one of the strongest arguments for the McGuire Act in 1952 was the haphazard enforcement of the Robinson-Patman Act (which, by the way, the Attorney General's Committee proposed to weaken further in a number of important respects). ${ }^{44}$ Certainly, Professor Herman's optimism about such laws as the Robinson-Patman Act stands in sharp and puzzling contrast to his pessimistic appraisal of the enforcement possibilities of the "free and open competition" proviso, which has had a shorter and perhaps less decisive history.

In my article I did not argue, nor do I now argue, that fair trade is an unequivocal blessing or that it represents the best way of facing up to the loss leader problem. My position was and is that, until a better solution is found, the fair trade laws, together with vigorous and effective enforcement of the

41. Id. at 751-52. A revealing aspect of the post-Schwegmann price-cutting flurry is the rapidity with which it petered out. By June 25, 1951, several Dun and Bradstreet field offices "indicated a waning of activity and interest in price cutting of fair-traded merchandise in their communities." See Study Prepared for the Joint Committee on the Economic Report and the Senate Select Committee on Small Business, Prevalence of Price Cutting of Mcrchandise Marketed Under Price-lMaintenance Agreenents May 28 through June 25, 1951, 82d Cong., 1st Sess., at vii (1951). Long before the McGuire Act was passed, therefore, the initial enthusiasm about price reductions had attenuated. The New York price war, it seems, was probably due more to the swollen inventories of wholesalers and retailers than to the Schwegmann decision, and it would be post hoc ergo propter hoc to attribute any causal relationship between the decision and the price war. See Adams, The Schwegmann Case: An Economic Comment, 15 U. DET. L.J. 13, 15 (1951).

42. Herman, supra note 1 , at 29 .

43. Report of the Atrorney General's National Committee to Study the AntiTRUST Laws 149-55 (1955).

44. Id. at 155-221. 
"free and open competition" clause, offer the most promising compromise of the conflicting considerations surrounding an admittedly knotty problem.

\section{Alternative Forms of Resale Price Maintenance}

With respect to vertical integration, consignment selling, agency, and refusal to deal, Professor Herman contends that there are disadvantages to each of these "alternative devices for maintaining resale prices, which make them less than perfect substitutes for fair trade." ${ }_{4 \mathfrak{5}}$

The generalization raises a number of questions. First, if these alternative devices are less effective than fair trade, why do they account for a far larger annual sales volume than does fair trade ${ }^{\text {?6 }}$ Second, assuming that the alternatives are more expensive than fair trade, are we to condone the alleged vices of resale price maintenance when it costs the manufacturer (and hence the consumer) more, but condemn resale price maintenance when it costs the manufacturer (and hence the consumer) less? Third, if fair trading manufacturers possess the market power that Professor Herman assumes, would the allegedly higher cost of the alternatives be an effective deterrent to adoption of resale price maintenance techniques other than fair trade? Fourth, if the alternatives are more costly than fair trade, would not the repeal of the Miller-Tydings and McGuire Acts disadvantage smaller manufacturers who would then find it more difficult than their more powerful rivals to protect trademarks and brand names? Fifth, is it accurate to say that an effectively policed fair trade system is less costly to the manufacturer than, say, a simple refusal to deal? (According to Herman C. Nolen, executive vice-president of McKesson and Robbins, it costs approximately $\$ 5,500$ just to notify distributors and retailers of a fair trade price change). ${ }^{47}$ Sixth, why are newspapers, magazines and periodicals sold

45. Herman, supra note 1 , at $30-31$.

46. In this connection, it is noteworthy that the Federal Trade Commission recently cited the following figures to indicate the growth of forward vertical integration in the American distribution system:

"Sales to or through own wholesale or retail branch stores .......... 24.5\%

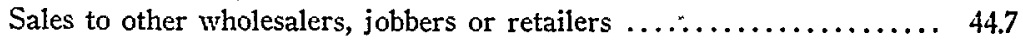

Sales to consumers at retail $\ldots \ldots \ldots \ldots \ldots \ldots \ldots \ldots \ldots \ldots \ldots \ldots, 1.6$

Sales to industrial and other large users $\ldots \ldots \ldots \ldots \ldots \ldots \ldots \ldots \ldots \ldots, 26.0$

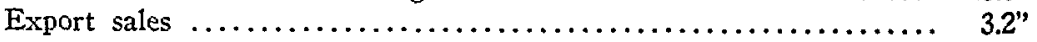

Eastman Kodak Co., Docket No. 6040, 3 CCH TRADE REG. REp. $\int 25291$, at 35422 n.24 (FTC Jan. 6, 1955). Speaking through Chairman Howrey (an avowed and unrelenting critic of fair trade), the Commission then took "judicial notice of the fact that many manufacturers are partially integrated and engage to a lesser or greater degree in some form of wholesaling or retailing activity. In fact, the volume of direct selling," said the Commission, "has reached tremendous proportions. This is so of manufacturers who 'fair trade' as well as with others. As a matter of fact, the practice of selling exclusively through the 'regular channels' of distribution is almost becoming the exception rather than the rule." The Commission then concludes-and significantly so-_"Sound business or economic reasons may justify such methods of distribution." Id. at 35422-23. This is the statement of a Commission which has consistently and vigorously opposed fair trade as a method of resale price maintenance.

47. Conference Board Economic Forumi, The "FaIr Trade" Question 39 (1955). 
on consignment rather than fair traded? What intrinsic market forces would make it less convenient and more costly to sell Colgate tooth paste on consignment than Life magazine? Of course, not each of the fair trading industries or each of the fair trading manufacturers would find the alternative devices readily available and effective substitutes for fair trade. Nevertheless, the facts remain that the economic effect of all forms of resale price maintenance is virtually the same, that fair trade today is quantitatively less pervasive than alternative resale price maintenance techniques, and that in the event of the McGuire Act's repeal, the alternative devices would surely be extended to some, if not all, industries now covered by fair trade. Finally, it is an incontrovertible fact that fair trade is explicitly subject to a "free and open competition" safeguard while the alternative devices are not. ${ }^{48}$

\section{Concluston}

Perhaps it is well to reiterate what should have been apparent-that my article was not an unqualified endorsement of fair trade in all industries, under all conditions, and in disregard of competitive considerations. One does not have to be a fanatic exponent of fair trade to concede that the case against fair trade has been vastly exaggerated, that the evidence against fair trade is ambiguous, and that fair trade-so long as it is practiced in an atmosphere of genuinely free and open competition-tends to safeguard the consumer against exploitation, protect the retailer against loss leader selling, and permit the manufacturer to defend his trademark and distributive system. Granted that fair trade is not the happiest formula for achieving these goals, it nevertheless is the most effective technique so far proposed. Certainly, if fair trade is to be condemned for its allegedly deleterious effects, consistency requires that we condemn other forms of resale price maintenance that produce the same effects.

As a member of the Attorney General's Committee I could not join in the majority recommendation for repeal of the Miller-Tydings and McGuire Acts, which contain the "free and open competition" safeguard, without a similar recommendation concerning alternative forms of resale price maintenance, which are quantitatively more significant and which are not subject to the same safeguard. In my view, the drive to repeal the fair trade laws is a dead end pursuit for the understaffed and inadequately financed antitrust agencies. More telling blows can be struck in the cause of competition by a strict enforcement of the "free and open competition" standard with respect to all types of vertical pricing arrangements, by actively prosecuting mergers that substantially lessen competition, and by ferreting out conspiracy and monopoly on the manufacturing level.

48. The "free and open competition" proviso currently sets forth an explicit control standard which is potentially applicable to all forms of resale price maintenance. It is, in a sense, an unequivocal expression of national policy on which the courts may rely not only in appraising fair trade practices but also in ruling on the legality of alternative resale price maintenance techniques. With the repeal of the Miller-Tydings Act, this standard would of course be wiped off the books. 


\section{THE YALE LAW JOURNAL}

\begin{tabular}{|c|c|c|}
\hline Volume 65 & DECEMBER, 1955 & Number 2 \\
\hline & $\begin{array}{l}\text { EDITORIAL BOARD } \\
\text { NORBERT A. SCHLEI } \\
\text { Editor-in-Chief }\end{array}$ & \\
\hline $\begin{array}{l}\text { David B. IsBELL } \\
\text { Article and } \\
\text { Book Review Editor }\end{array}$ & $\begin{array}{l}\text { GERALD M. DOPPELT } \\
\text { JON O. NEWMAN } \\
\text { RTCHARD H. PERSHAN } \\
\text { Note and Comment Editors }\end{array}$ & $\begin{array}{c}\text { STEPHEN J. PoLIAK } \\
\text { Managing Editor }\end{array}$ \\
\hline \multirow[t]{2}{*}{$\begin{array}{l}\text { IRVING J. ALTER } \\
\text { BENJANIN H. BALKXND } \\
\text { MALVIN E. BANK } \\
\text { JOHN W. BARNUM } \\
\text { AXEL H. BAUMI } \\
\text { MELVIN L. BEDICK } \\
\text { C. WILLIANI BERGER } \\
\text { DANIEL M. BERGER } \\
\text { NEIL N. BERNSTEIN } \\
\text { ROBERT W. BLANCHETTE } \\
\text { JUDITH MYYRA BLEICH } \\
\text { JAMES H. BRATTON, JR. } \\
\text { ALAN P. COLODNY } \\
\text { EDMUUND V. CONWAY } \\
\text { J. RICHARD DUFFIELD } \\
\text { H. EDW. DUUNELBERGER, JR. } \\
\text { RODNEX E. EYSTER }\end{array}$} & $\begin{array}{l}\text { GERALD T. FLOMT } \\
\text { ALVIN FRIEDMIAN } \\
\text { VICTOR S. FRIEDMIAN } \\
\text { IIORTON I. GREENBERG } \\
\text { MIITON S. GWIRTZMAAN } \\
\text { ROBERT J. HARRIS } \\
\text { GEORGE C. HASTINGS } \\
\text { IRA MIICHAEL HEYMAN } \\
\text { BUD GEORGE HOLNAN } \\
\text { WILLIAM E. HUTH } \\
\text { CEARLES D. ISAAC } \\
\text { LLOYD J. KENO } \\
\text { LAWRENCE R. KLEIN } \\
\text { DAVID KLINGSBERG } \\
\text { HAROLD S. LEVY } \\
\text { IRWIN A. LEVY } \\
\text { JULIUS LEWIS } \\
\text { ARTHUR L. LIMAN }\end{array}$ & 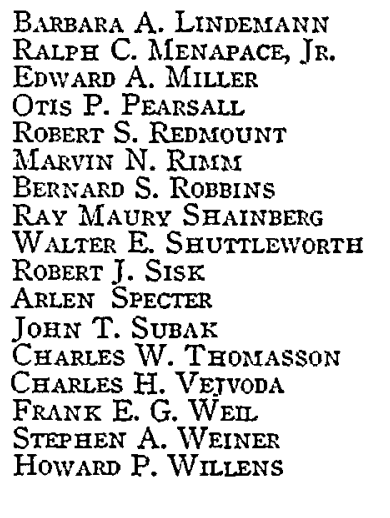 \\
\hline & $\begin{array}{l}\text { MaRIE MCMAEON } \\
\text { Business Secretary }\end{array}$ & \\
\hline
\end{tabular}

\section{CONTRIBUTORS TO THIS ISSUE}

Grorge H. Desston. A.B. 1926, A.M. 1927, Cornell University; LL.B. 1930, Yale University. Late Professor of Law, Yale Law School. Author: Crimnal Law, AdarinisTRATTON AND PuBlic ORder (1947).

Harold D. Lasswell. Ph.B. 1922, Ph.D. 1926, University of Chicago. Professor of Law and Political Science, Yale University. Fellow, Center for Advanced Behavioral Studies, Stanford, California. Author: Psychopathology and Politics (1930); World Politics and Personal Insecurity (1935); Politics: Who Gets What, Waen, How (1936); The Analysis of Political Behanour (1948) ; Power and Personality (1948); Natronal Security and Individual Freedom (1950). Co-author: (Leites) Language of Politics: Studies in Quantitative Semantics (1949); (Kaplan) Power AND SOCIETY (1950).

Elvin R. LAtTy. B.S. 1923, Bowdoin College; J.D. 1930, University of Michigan; J.Sc.D. 1936, Columbia University. Professor of Law, Duke University School of Law. Author: Subsidiartes and AfFiliated CoRporations (1936); Introduction to Business Assoctamions (1951).

Walter Adanis. A.B. 1942, Brooklyn College; M.A. 1946, Ph.D. 1947, Yale University. Associate Professor of Economics, Michigan State University. Member, Attorney General's National Committee to Study the Antitrust Laws. Author: THe Strucrure of American Industry (1950); Monopoly in Amirrica: The Governnent as Promoter (1955). 